\title{
Are There Non-linear Effects of Banking Relationships and Ownership Concentration on Operational Performance? Empirical Evidence from Portuguese SMEs Using Cross-section Analysis and Panel Data
}

\author{
António Pedro Soares Pinto ${ }^{1} \&$ Mário Gomes Augusto ${ }^{2}$ \\ ${ }^{1}$ Polytechnic Institute of Viseu, Campus Politécnico, Viseu, Portugal \\ ${ }^{2}$ University of Coimbra, Avenida Dias da Silva, Coimbra, Portugal \\ Correspondence: António Pedro Soares Pinto, Polytechnic Institute of Viseu, Campus Politécnico, 3504-510 Viseu, \\ Portugal. E-mail: spinto@estv.ipv.pt
}

Received: July 9, 2014

doi:10.5430/ijfr.v5n4p67
Accepted: July 30, 2014

Online Published: August 24, 2014

URL: http://dx.doi.org/10.5430/ijfr.v5n4p67

\begin{abstract}
This paper provides new evidence for the relationship between the stability of the banking relationship, ownership concentration and operating profitability, supporting non-linear effects between those variables in the context of small and medium enterprises (SMEs). From a sample of 4,163 Portuguese SMEs and cross-section data and panel data, we found evidence for a U-shaped quadratic relationship between the stability of the banking relationship and operational performance. This result indicates that the consolidation of new banking relationships, the difficulties experienced by SMEs in overcoming the problems of adverse selection and moral hazard reflect negatively on their operating profitability. However, when the banking relationship is solidified, and banking institutions acquire information, supervision and monitoring costs decrease, credit constraints are lower and contractual conditions are tailored to the needs of the company, with positive impacts on operating profitability. In turn, the quadratic specification established between ownership concentration and operating profitability suggests that the expropriation hypothesis prevails for low levels of control rights and the supervision hypothesis prevails for high levels.
\end{abstract}

Keywords: stability of the banking relationship, ownership concentration, operating profitability, nonlinear effects, panel data

\section{Introduction}

In economies where bank financing is particularly important in financing enterprises in general and SMEs in particular, understanding how the stability of the banking relationship may affect access to credit as well as its cost and consequently profitability is of particular importance both for businesses as well as for conducting economic and fiscal policy in these economies (Fazzari et al., 1988). Moreover, SMEs are particularly important in terms of economic activity, employment and innovation in most countries (Behr et al., 2013).

Stability and development of the banking relationship in a credit market characterized by information asymmetries may be an important competitive advantage both for SMEs, heavily dependent on bank credit, and for the financing bank. The financing bank reduces information asymmetry insofar as it appropriates private information over the course of the relationship, and SMEs see the possibility of improving medium-term funding conditions in quantity and price in that reduction (Vigneron, 2001, Cánovas and Solano, 2007, Shimizu 2012, among others). The relationship the bank has with the company, expanded and consolidated with its stability and duration, gives it greater knowledge and an improved ability to oversee credit agreements (Udel 2008, Behr et al., 2013). It thus becomes possible to increase the availability of credit, offer services that will best meet the needs of the company, gradually decrease the risk premiums and fund projects that may not be viable in the short term, but may be so in the medium and long term (Boot, 2000, Dass and Massa, 2011).

Nevertheless, there is no lack of arguments in the literature that the benefits of stability in the banking relationship cannot be equally divided among the different parties involved. With the deepening of the banking relationship, the financing bank may be able to capture the company informationally, making it more difficult for the company to change lenders with the expected impacts on the amount and cost of credit, on financial constraints placed on new credit agreements and consequently, on investment and company performance (eg, Fazzari et al., 1988, Kaplan and 
Zingales, 1997, Beck et al., 2005, 2006, Whited and Wu, 2006, Almeida and Campello, 2007, Hadlock and Pierce, 2010 Torre et al., 2010).

SMEs can reduce the problems of asymmetric information with regards to the credit institution. As Boot (2000) mentions the existence of a bank relationship allows the financial intermediary to obtain the company's private information through multiple interrelationships over time and from providing various financial services. However, information asymmetry evolves between the bank in the relationship and other entities, conferring monopoly power on that bank. Thus, if on the one hand the stability of the banking relationship can positively affect the company's performance, on the other it can have perverse effects. Knowing which effect prevails is still an open question. In this sense, a first issue under examination in this paper is on the effects that the stability of the banking relationship can have on SME profitability.

In addition, by virtue of the importance it has assumed in the literature, ownership concentration - and its effects on governance mechanisms - as a vehicle with a particular influence on agency costs and, consequently, SME profitability (Thomsen, 2005 Minguez-Vera and Martin-Uego 2007, Chu, 2009 Arosa et al., 2010) as well as the divergence of results that the very literature has provided, we intend to provide additional evidence of the effect of ownership concentration on the company's operational performance.

Dispersion of ownership creates free-riding problems making supervision difficult such that high ownership concentration induces greater involvement in decision-making allowing the benefits of the greater supervision effort to be internalized (Grossman and Hart, 1986, Maury, 2006 Dahya et al., 2008). However, a high concentration of ownership may also give rise to costs, to the extent that private benefits for majority shareholders over minority owners in the absence of coincidence of interest stem from greater control (Shleifer and Vishny, 1997 Villalonga and Amit, 2006). The coexistence of these two arguments (supervision hypothesis and expropriation hypothesis) suggests that ownership concentration has a nonlinear relationship with the performance as claimed by Chen et al. (2004), Michael et al. (2004), Hu and Izumida (2008).

This paper is organized as follows: besides this introduction there are four sections. The second section is devoted to reviewing the relevant literature on the subject. The third section describes the methodology used. The fourth section turns to the sample, data and variables. In the fifth section the results are presented and discussed. Finally, the sixth section presents the main findings of this study.

\section{Literature Review}

The banking relationship fosters the production and sharing of information between the different stakeholders. This is often imperfectly provided by those applying for credit and under many circumstances lacks preliminary evaluation of credibility. Under these circumstances, banks pay particular attention to the type, quantity and quality of information that can be collected during the banking relationship and to all of the signals emitted by the credit applicant, providing valuable assistance towards establishing the amount of credit granted and its price. The presence of information asymmetries in the banking relationship causes problems whose solution has costs, including agency costs. These are particularly felt when those applying for credit are small size and/or tend to be opaque, as is the case with SMEs (Psillaki 1995, Torre et al., 2010).

In the credit market, the presence of information asymmetries is revealed when companies have exclusive and private information which is difficult to transfer to the lender regarding the intrinsic characteristics and particularities of their projects (Schenone, 2010). This allows companies to devise their strategies with some flexibility, creating difficulties for banks to distinguish different risk levels among the credit applicants, (Langlais, 1999). This leads to adverse selection which prevents banks from practicing active differentiated interest rates and credit contracts adjusted to the risk level of the applicants. The difficulty in distinguishing "good" companies from "bad" ones creates the first obstacles to credit access increased by the significant presence of the latter (Berndt and Gupa, 2009, Ivashina, 2009). Moreover, the creditor bank may find difficult to control the company's behavior after celebrating the credit agreement, causing so-called moral hazard (Torre et al., 2010). Under these circumstances, the bank will require a priori interest rates and higher collateral as well as more restrictive contractual terms. This problem is particularly felt by SMEs, often causing them forego value-creating investment opportunities, affecting their performance (Valverde et al., 2009, Canovas and Solano, 2010).

In generating adverse selection and moral hazard problems, information asymmetries impose upon companies increased costs and difficulties in the availability of debt capital financing. In many circumstances access to credit is excluded for firms which are more highly exposed to these kinds of problems (Torre et al., 2010). Adverse selection promotes an increase in the interest rate and causes two effects of conflicting signals about the bank's expected return: 
on the one hand, in the case of customers servicing their debt, expected return is seen to increase; on the other hand, in the case of default, risk increases and the return decreases (Stiglitz and Weiss, 1981). From a certain amount, the second effect overrides the first in which an increase in the interest rate leads to a decrease in the bank's return (Berndt and Gupta, 2009, Bharath et al., 2011). Under these circumstances, the bank no longer has incentives to increase the interest rate, preferring instead to ration credit. Thus, adverse selection and moral hazard exercise counterproductive effects on returns to the extent that in receiving the amount established contractually, banks do not benefit from borrowers' high profits (when they occur), but they do incur losses when the company cannot service their debt.

The problems that information asymmetry in the credit market yields lead banks to adopt analytical techniques (screening) in the pre-contractual stage to streamline the process of selecting credit applicants. In the post-contractual stage, banks develop supervision and control techniques (monitoring) by putting a range of mechanisms in place, to enable companies that deviate from what had been agreed to be penalized and thereby minimize agency costs (Ramakrishnam and Thakor, 1984). One means of control exercised over the borrower's credit is to use short or medium term bank debt to finance long-term projects. So the company is forced to periodic renegotiation of contractual terms requiring it to engage in "correct" behaviour to maintain funding on reasonable terms until the end of the project (Diamond, 1984, Leland and Toft, 1996, Leland, 1998, Park, 2000, among others).

Against the background of information asymmetry, intensifying the banking relationship allows negotiating flexibility to be incremented, control by credit entity to be increased and reputation and confidentiality to be developed (Canovas and Solano, 2007, Bharath et al., 2011). Thus, bank negotiations might resolve the a priori inefficiencies of allocating resources and the a posteriori monitoring of the profitability of the projects.

Establishing lasting relationships between the company and the credit institution allow valuable information to be revealed about company quality. In this regard several studies (e.g., Elsas, 2005, Puri and Rocholl, 2008) reported that the bond established with the financial intermediary is enhanced by maintaining an exclusive relationship. This provides the company with increased availability of credit, better conditions for funding and a reduction in the required collateral. When only one institution extends credit, it bears all the risk generated as well as the yield of its decisions. It eliminates the free-riding problem and is endowed with greater flexibility to play the role of intermediary. Development of the relationship reduces information asymmetries, with banks paying particular attention to the type, quantity and quality of information that can be collected (Stiglitz and Weiss, 1981, Schenone, 2010). However, one cannot ignore that bilateral relations may also generate problems. Sharpe (1990) and Rajan (1992) argue that firms that are financed by a single bank find themselves caught informationally, since no other institution knows their true risk. Under these circumstances, the financial institution can use the informational monopoly to its advantage, imposing higher costs or creating constraints on funding, with inherent consequences to the profitability of companies seeking financing (Schenone, 2010). Thus, multilateral relationships provide information on the real risk to a greater number of intermediaries, allowing availability of credit to be increased (Detragiache et al., 2000 and Farinha and Santos, 2002).

The instruments used by banks to address the possible information asymmetries include the practice of differentiated interest rates and collateral, inducing "good" applicants to disclose their information. Noting that it is difficult, if not impossible, to identify the "good" applicants among all of them and to control their future actions and results, the lender needs to use a wide variety of mechanisms to select and supervise (Degryse et al., 2011). These include imposing contractual obligations on the borrower's credit, whether in terms of providing information and transparency, or through constraints on freedom of action. In this process SMEs are faced with added difficulties due to either the lack of economies of scale they provide the financing bank, or by virtue of the high volatility of results they present (De la Torre et al., 2010, Castelli et al., 2012). Thus, the inability to quantify inherent risk, banks ration credit imposing debt ceilings. If monitoring costs are a significant burden relative to the size of the project, the banks decline conceding credit, preferring to finance large projects and large companies by virtue of the economies of scale they provide (Canovas and Solano, 2007).

Nevertheless, there is a growing empirical literature which evaluates the effect of the number of bank relationships on corporate performance, such that to our knowledge, there has not been a study as of yet that evaluates the effect of stability in the banking relationship on SME performance.

In the case of Portuguese companies by virtue of the internationalization process that they have been subjected to, we have witnessed transformation processes characterized by: $i$ ) a growing separation between ownership and control, and ii) an opening of their equity to outside investors. This presents us with a new paradigm reflected in the need to evaluate how some mechanisms for monitoring and oversight of governance affects corporate performance. Several supervision and control mechanisms help reduce the discretionary behaviour of agents, including directors, related to the purpose of maximizing company value. These mechanisms include: $i$ ) the external context: the labour market, the 
capital market, the market for goods and services, and the legal/political system, constituting disciplinary mechanisms regarding actions by directors, helping to align the goals and interests of the agent and the principal (Harford et al., 2008, Goergen and Renneboog, 2008), and ii) internally: ownership concentration, the insider ownership, the nature of ownership, the composition of the managing bodies (directors), the level of debt, the remuneration system and dividend policy (Cuervo, 2002, Andres, 2008).

As it is difficult to gather consensus on the relevance of different control mechanisms and the literature suggests different ways to quantify them, ownership concentration is given in this study emphasis since this is a simple intuitive mechanism, less prone to measurement error and not subject to the problems of weighting. Ownership concentration, as a corporate governance mechanism, appears as a determinant of agency costs (Jensen and Meckling, 1976). Based on this premise, the effect of ownership concentration on performance has been widely documented in the literature, particularly for companies in the United States, the UK and China (Bhattacharya and Ravikumar, 2001, Gadhoum et al., 2005 Villalonga and Amit, 2006, Ma et al., 2010).

Dispersion of ownership creates free-riding problems and makes supervision difficult. Increasing concentration is expected to have a positive impact on company performance. Consistent with the supervision hypothesis, Shleifer and Vishny (1986) argue that the important role played by major owners and how share price rises with the percentage they hold. Owners with high equity participation show greater willingness to play an active role in decision making, in that they internalize the benefits of their monitoring effort (Bennedsen et al., 2007 Eddleston et al., 2008 Dahya et al., 2008 Tsionas et al., 2012).The method used by owners to oversee management results from informal agreements among themselves (Shleifer and Vishny, 1997). However, ownership concentration can lead to conflicts between controlling owners and minority shareholders, resulting in worse performance, as proposed by the expropriation hypothesis. Divergences induce a generalized perverse problem where controlling owners expropriate the wealth of minority owners (Byun et al., 2011). Small investors fear being expropriated due to inefficient investments, which entail high costs for the company (La Porta et al., 1999). Shleifer and Vishny (1997) argue that in some countries, agency problems arise mainly from the conflict between controlling and minority owners. Thus, high stakes can generate costs, particularly when the majority owners do not redistribute wealth equitably with minority owners, because interests do not always coincide.

Several authors have analyzed the relationship between ownership concentration and performance, determining the existence of an optimal structure. For example, in a study of listed companies in the UK, Leech and Leahy (1991) documented an inverse linear relationship between ownership concentration and performance. The same relationship was observed by Mudambi and Nicosia (1998), Lehmann and Weigand (2000) and Psillaki and Margaritis (2010) for a sample of English, German and French companies, respectively. Similarly, Hamadi (2010) argues that large shareholders have a negative effect on the company's performance; however, in family businesses, this effect is positive. Moreover, there is no shortage of empirical studies showing evidence that ownership concentration has a positive effect on company performance. This relationship is validated, for example, by Hill and Snell (1988) and Agrawall and Mandelker (1990) in the context of the North American companies, Kaplan and Minton (1994) and Gedajlovic and Shapiro (1998), in the case of Japanese firms, Gorton and Schmid (2000) for German companies, Ehikioya (2009), in Nigerian companies and Ma et al. (2010) and Kurt et al. (2010), in the context of Chinese enterprises.

Gedajlovic and Shapiro (1998) warn that investors in the Japanese institutional context are somewhat protected by the legal system and ownership is highly concentrated. Thus, contrary to what occurs in other countries, minority owners are not expropriated as banks play an important role in corporate control, leading to convergence of interests among equity holders and between themselves and managers. However, when the dominant owners have enough power to control, they may be tempted to maximize personal wealth at the expense of maximizing company value, leading to a conflict of interests between majority and minority owners. Accordingly, when analyzing listed companies in Spain, Miguel et al., (2004) realize there is a nonlinear relationship, noting an increase in market for ownership concentration values below 87 percent as a result of the supervision effect, but above this level minority shareholders are expropriated through a decrease in the value of the company. There is, thus, an inverted-U shaped relationship. The authors offer an explanation of the results by referring to a set of institutional characteristics inherent in the Spanish corporate governance system, which differentiates it by among other things: the level of ownership concentration, the effectiveness of their boards of directors, capital market development, in the corporate control market activity and investors' legal protection. Emma and Juan (2011) obtained similar results in a study of listed Spanish companies between 1999 and 2002, which concluded that ownership concentration positively influences company value, but for high levels a perverse effect emerges. Other authors (e.g., Anderson and Reeb, 2003 Maury, 2006) also establish a non-linear relationship between ownership concentration and performance, diverging, however, as to the point from 
which the supervision effect replaces the expropriation effect. This divergence arises from the different corporate governance systems, investors' legal protection, capital market development, the role of the market in controlling the business, the industry, among others (Shleifer and Vishny, 1997, La Porta et al., 1998).

In a more recent study, Arosa et al. (2010), in turning to Spanish private equity SMEs, found no relationship between ownership concentration and corporate profitability, i.e., no evidence corroborating the of supervision and expropriation hypotheses. In this case, the level of ownership concentration has no direct influence on the behaviour of the owners, which may be related to the status and ownership structure of unlisted companies. Nevertheless, when the sample is divided according to the nature of the ownership, the results suggest that the relationship between ownership concentration and performance changes as a function of the firm being run by the founder or his heirs. In first-generation family businesses, a positive relationship between ownership concentration and performance is observed for low levels of control rights (up 49\%), with the supervision hypothesis prevailing, and a negative relationship for high levels of concentration, as a result of the expropriation hypothesis. In the same vein, Chu (2011), studying Thai companies, concluded that the association between the concentration of family ownership and performance is more intense in small firms.

Izumida and $\mathrm{Hu}$ (2008), who studied the causal relationship between ownership concentration and performance in the context of Japanese manufacturing firms, suggest a U-shaped relationship in line with the predominant effect of expropriation at low levels of ownership and the supervision effect at higher levels, which is associated with better performance.

The impact the banking relationship's stability on profitability in a context of asymmetric information (adverse selection and moral hazard) is determined by several factors: some positive and some negative. It is therefore pertinent to study how banks and companies are sharing the value created in credit relationship. The literature also reveals that it has been difficult to obtain a consensus on the role of ownership concentration on profitability as it is conditioned by two prevailing effects (the supervision and expropriation hypotheses). Bearing in mind the state of the art in this field, this paper's concerns focus on studying the nonlinear effect of the stability of the banking relationship and ownership concentration on the operating profitability of Portuguese SMEs, as shown in Figure 1:

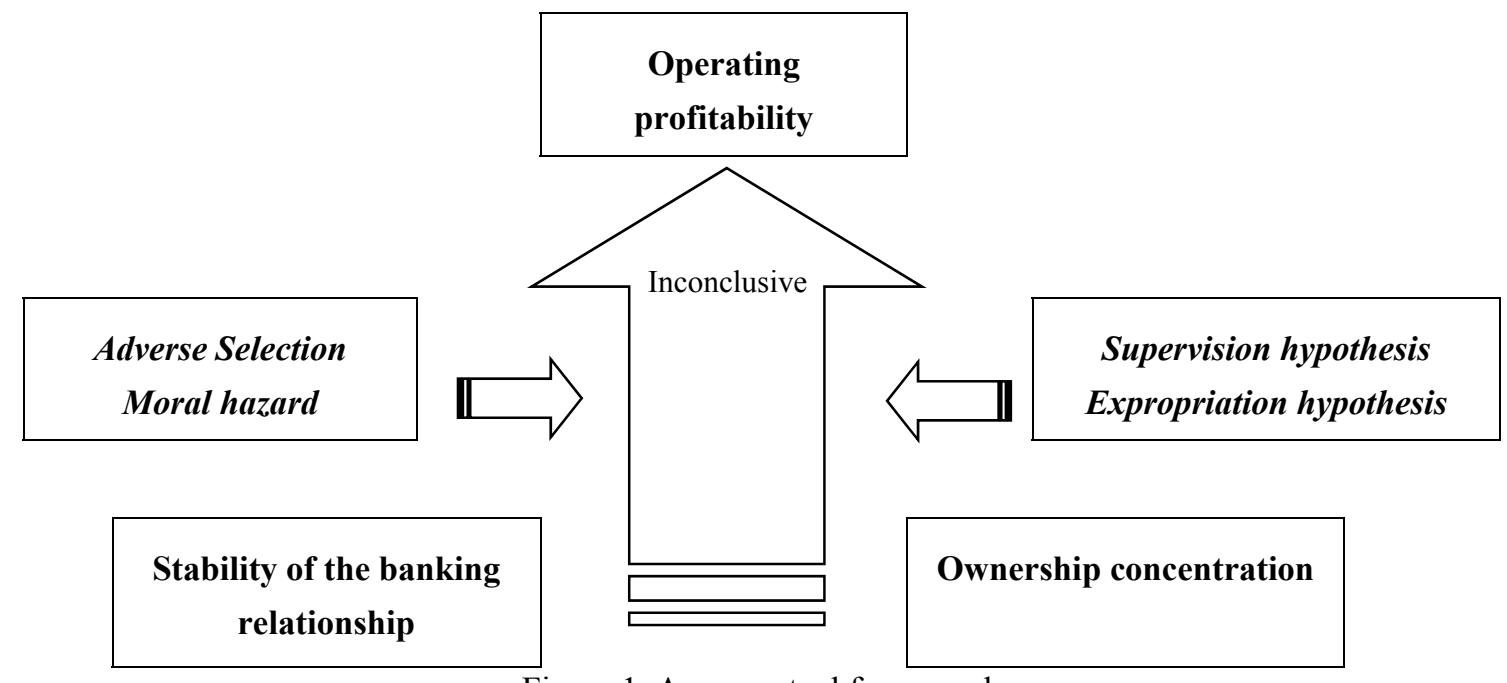

Figure 1. A conceptual framework

\section{Methodology}

As mentioned above, information asymmetries create increased difficulties for companies in general and SMEs in particular in terms of adverse selection and moral hazard, leading many of them to forego good investment opportunities. Stability of the banking relationship can help to mitigate these problems by providing the financing bank economies of scale in gathering and processing information and thus reducing supervision and monitoring costs, minimizing the free-riding problem and creating greater flexibility in contractual terms (Boot et al., 1993, Bharath et al., 2011). Being exposed to lesser asymmetries, SMEs will see their medium-term financing conditions improve in terms of quantity and price as they simultaneously face fewer restrictions imposed by financing agreements. However, this competitive advantage resulting from the stability of the banking relationship only becomes effective for both parties if the relationship bank does not capture company informationally, making it more difficult to change lenders 
with the due repercussions on quantity and cost of credit, the financial constraints placed in new credit agreements, and consequently on investment and performance. Knowing which of these opposing effects on SME operational performance that may result from the stability of the banking relationship tend to prevail continue to this day to be an issue that has not generated a consensus on the part of existing research. In this sense, based on the suggestions that point to a non-linear relationship between the stability of the banking relationship and corporate performance, the following model was formulated:

Operational performance of the company $=\beta_{0}+\beta_{1}$ Banking Rel. Stab. $+\beta_{2}$ Banking Rel. Stab. ${ }^{2}+\beta_{3}$ Age $+\beta_{4}$ Company

$$
\text { Size }+\beta_{5} \text { Debt }+\varepsilon
$$

With regard to the relationship between ownership concentration and profitability, it is also difficult to find a consensus in the literature. On the one hand higher concentration allows for greater supervision, on the other hand it can lead the controlling owner to enjoy private benefits by expropriating the company. To evaluate these effects, the model formulated has the following specification:

Operational performance of the company $=\beta_{0}+\beta_{1}$ Ownership concent. $+\beta_{2}$ Ownership concent. ${ }^{2}+\beta_{3}$ Age $+\beta_{4}$

$$
\text { Company Size }+\beta_{5} \text { Debt }+\varepsilon
$$

Despite the existence of multiple variables which may condition the relationships under study and taking the two main objectives of this study into account, only those which have deserved greater attention on the part of existing research have been considered, namely: the age of the company, its size and its level of debt.

According to Degryse and Van Cayseele (2000) and Sakai et al. (2010) age reflects reputation openly convey to the market, constituting a valuable complement to the private information that banks acquire during the relationship, facilitating, among other things, risk analysis by banks outside the relationship. In reflecting public information about the company's survival and maturity, it is an indicator that prior commitments have been met. It thus constitutes an intangible asset that is perceived by banks outside the relationship without incurring the high costs of collecting and processing information. However, one cannot also ignore that companies, like people, have a finite life expectancy (Reis and Augusto, 2013). As such, if on the one hand, age represents maturity and experience in the past, on the other, it also reflects the number of years that the company can expect to generate cash flows and results, and thus has a negative effect on performance. Moreover, in the case of SMEs, age may also have associated generational effects from incorporating later generations with its founders with corresponding effects on performance. With increasing age the probability of the company's ownership coming to be shared by an increasing number of parties increases, as well the conflicts that can arise if interests are not aligned, and in many circumstances the operational choices driven by personal preferences with resulting effects which will impact company performance (Chrisman et al., 2005 and Sharmaa et al., 2007).

As Bonfim et al. (2010) highlight, the size of the company cannot be ignored when studying the effect of the stability of the banking relationship and ownership concentration on performance. Larger firms have greater negotiating power in their relationships with credit institutions. In addition to being subject to lower information asymmetries, is is far easier for them to establish new banking relationships, compared to small and micro enterprises. It is more difficult for small businesses to establish new banking relationships by virtue of adverse selection and to the informational opacity to which they are subject. The high risk they represent, the supervision and monitoring cost required inhibit establishing new relationships (Degryse et al., 2011). Where these costs represent a significant weight relative to the size of the project, banks decline granting credit, preferring companies that provide economies of scale (Canovas and Solano, 2007).

Whilst it is true that we find arguments that indicate size has a positive effect on the company's operational performance, supported by economies of scale and reduced fixed costs (Larmou and Vafeas, 2010) and in the diversified range of products (services) that produces (renders) (Torre et al., 2010), it is no less true that arguments can be found that indicate the opposite effect. In small and micro enterprises in particular, ownership is highly concentrated and hence the simultaneous role of owner and manager, by an individual or family, characterized by a reduced propensity to risk and very careful analysis of investments may condition performance. On the other hand, this coincidence between ownership and management contributed to minimizing the agency costs of equity which has a positive impact on these companies' performance (Andres, 2008).

SMEs face severe limitations when they require external funding. Their ownership structure, which is usually concentrated, is a serious impediment to issuing new capital due to the reluctance of the current owners to share company control with new owners. Thus, given the strong constraints that SMEs have in accessing external funding (either through new capital, or through outsider equity), debt level may be an important signal with regards to the 
quality of company assets as well as its projects; it may therefore be a differentiating element at the corporate level. However, one cannot forget that in the context of these companies, by virtue of the asymmetries they are subject to, adverse selection and moral hazard problems come up, which naturally translates into rising cost and even rationing of credit. This credit rationing, well demonstrated by Myers and Majluf (1984), may impede acceptance of value-creating projects and even the viability of the company itself, with effects on operating profitability. Moreover, the scarcity of equity gives it a highly leveraged financing structure, creating strong incentives in the banking system to interfere in current management decisions in the medium and long term, with implications for its operational performance (DeAngelo et al., 2002).

\section{Sample, Data and Variables}

\subsection{Sample and Data}

The SMEs selected to be studied were those which possess a set of particular characteristics that separate them from the others. Firstly, in most cases they are closely held companies subject to greater information problems when compared to larger firms. For smaller, normally younger and more informationally opaque companies, the inability to credibly disclose their quality, combined with a lack of separation between ownership and management, information asymmetry significantly increases between insiders and outsiders. Thus, the value of the banking relationship based on reciprocity of soft information is particularly relevant in the context of these companies (Torre et al., 2010). Secondly, small firms are limited in obtaining external funds from financial institutions insofar as the market is only accessible to large companies. Thirdly, these companies are of particular importance in most economies and Portugal is no exception. According to the study by IAPMEI's Office of Planning and Studies (February 2008) SMEs represent 99.6\% of the business units in Portugal, creating $75.2 \%$ of private employment and performing over half of the turnover (56.4\%), generating about 2.1 million jobs and over 170.3 billion euros in turnover.

This study turns to a set of non-financial companies with information for the period from 2003 to 2007. SABI (Iberian Balance Analysis System, version 33.1, update 110 - October, 2008), which contains accounting and financial information on Portuguese and Spanish companies, was the main source of information. From all the enterprises contained in the database, a sample of 4,163 companies was selected. This sample resulted from imposing the following filters: $i$ ) companies that had no accounting information during the review period were eliminated from the database, ii) only those which met the conditions set by the Bank of Portugal in their analyses (Total Assets, Equity, Turnover and positive GVA) were included, iii) only firms that presented economic viability expressed by positive operating profitability were retained, iv) only those which met the conditions for SMEs under Decree-Law No.372/2007 (Note 1) were retained, $v$ ) all those for which it was impossible to collect information on the number of credit institutions were excluded from the base, vi) companies in the financial sector were excluded and finally, vii) only those companies for which information concerning equity distribution was available were retained.

Table 1 shows the distribution of sample firms by number of employees. As shown, $89 \%$ of companies have fewer than 50 workers. However, it is those with 10 or more workers which absorb $90 \%$ of labour and represent $83 \%$ of turnover. A significant number of companies (43\%) have fewer than 10 employees; however, their contribution to generate business and create value is of little relevance. Although the number of companies with 50 or more people is reduced (11\%), they absorb $45 \%$ of the workforce and account for $36 \%$ of turnover.

Table 1. Sample - Main characteristics by size class (number of employees), mean values 2003-2007

\begin{tabular}{lrrrrrrr}
\hline Variáveis & \multicolumn{1}{c}{ Total } & \multicolumn{2}{c}{ Less than 10 } & $\mathbf{1 0 - 4 9}$ & \multicolumn{2}{c}{$\mathbf{5 0 - 2 4 9}$} \\
\cline { 2 - 8 } & Amount & Amount & $\%$ & Amount & $\%$ & Amount & $\%$ \\
\hline Companies (No.) & 4.163 & 1.777 & 43 & 1.928 & 46 & 458 & 11 \\
Employees (No.) & 94.539 & 9.504 & 10 & 42.422 & 45 & 42.612 & 45 \\
Turnover (10 ${ }^{3}$ Eur) & 12.313 .887 & 2.037 .058 & 17 & 5.796 .657 & 47 & 4.480 .172 & 36 \\
\hline
\end{tabular}

\subsection{Variables}

A company's performance is often assessed either by market indicators, or by accounting information. SMEs involved in the stock market are rare, being funded preferentially through bank intermediation. It is thus impossible to obtain information which allows market evaluation from to be carried out. Thus, studies which study SMEs find themselves naturally having to resort to accounting information for the purpose of measuring this attribute. The most commonly used indicators include: $i$ ) the operating return on assets (ROA) (e.g., Aras et al., 2010, Greenaway et al., 2012, Masulis et al., 2012, Castelli et al., 2012, Wang and Sarkis, 2013) and ii) return on equity (ROE) e.g., Griner, 2011, 
Ding et al., 2012, Komnenic and Pokrajcic, 2012, Woodcock, 2012). Considering the arguments presented in the literature, our choice was ROA. This choice is related to the fact that it allows performance of the total capital invested in the company to be evaluated, regardless of its source (from inside or out), and it is one of the best indicators to compare companies. On the other hand, it determines the survival of the company in the long term and its capacity to attract capital, either internally or externally. Joh (2003) even argues for the superiority of this indicator compared to those based on market information, maintaining that: $i$ ) stock price does not reflect the total information available in the absence of efficient market valuation, ii) there is empirical evidence that accounting profitability has a stronger association with the firm's survival than Tobin's Q, and iii) it allows the performance of companies not traded in the stock market to be evaluated.

ROA measures the company's performance and reflects the return on investments. An additional advantage of this indicator stems from the fact that it is not directly influenced by the company's capital structure. Thus, an a posteriori relationship with the control variable considered in our analysis, debt ratio, is avoided. In accordance with what is unanimously accepted, this indicator is operationalized by the quotient between operating results (OR) and total assets (TA).

To measure the stability of the banking relationship, as Canovas and Solano (2010) suggest, we chose by the quotient between the number of ordinary banks and the number of banks with which the company has established relationships throughout the period of our analysis (2003-2007). Its value ranges from zero (none of the banks remains throughout the period) and one (the company maintains relationships with all of them).

A review of empirical studies reveals the use of different indicators to measure the degree of ownership concentration, dividing them into two groups: discrete and continuous. Discrete indicators assume values between zero and one according to the participation of the majority owner or the sum of a group of owners. Demsetz and Lehn (1985), Dennis et al. (2000), among others, use such indicators, and they are particularly useful when it one wants to compare the performance of dispersed versus concentrated structures. Continuous indicators, in turn, may assume a multitude of values within a range. In line with Psillaki and Margaritis (2010) and Brutonline et al. (2010), this study used the percentage of equity held by the two largest owners as the measure of ownership concentration.

Company size has also been measured by a very broad set of indicators. For example, Degryse and Ongena (2001) and Bhagat and Bolton (2008) consider the logarithm of sales, Berger and Udell (1995), the total net assets, Cardone et al. (2005) the number of employees. In our study company size is measured by the logarithm of total net assets as recommended by Petersen and Rajan (1994), De Bodt et al. (2005), Andres (2008), among others. Following Berger and Udell (1995), Harhoff and Körting (1998), Degryse and Van Cayseele (2000) and Sharmaa et al. (2007), among others, age was chosen to measure the company's reputation, i.e., the number of years since its incorporation. Capital structure has also been measured by a wide range of indicators, which can be separated into two groups: one includes those that take into account total assets (application of resources) and fund source, others focus only on the latter. In line with Bolbol et al. (2004), Fok et al. (2004), Augusto et al. (2011), among others, our choice fell on one of the indicators included in the second group, i.e., the ratio of interest-bearing liabilities and equity.

Table 2 presents a summary of the indicators used to measure operating profitability, stability of the banking relationship, ownership concentration, company reputation, size and debt level as well as how to operationalize them. In selecting indicators concern was taken not to include the same variables that were correlated a priori with what they are purported to explain. Table 3 shows the main descriptive statistics of each of these indicators.

Table 2. Summary of selected variables and their operationalization

\begin{tabular}{lll}
\hline Designation & & Expression \\
\hline $\begin{array}{l}\text { Operating } \\
\text { Profitability }\end{array}$ & Return on assets & Operating result/Assets \\
\hline $\begin{array}{l}\text { Banking } \\
\text { Relationship }\end{array}$ & Stability of the relationship & Number of common banks/Number of banks \\
& & \\
\hline $\begin{array}{l}\text { Ownership } \\
\text { Structure }\end{array}$ & Ownership concentration & $\begin{array}{l}\text { Ownership held by two majority owners/Total } \\
\text { Ownership }\end{array}$ \\
\hline \multicolumn{1}{c}{$\begin{array}{l}\text { Control } \\
\text { Variables }\end{array}$} & Company size & Natural logarithm of total net assets \\
\cline { 2 - 3 } & Age & Number of years since incorporation \\
\hline
\end{tabular}


Table 3. Descriptive statistics of selected variables

\begin{tabular}{lrrrr}
\hline & Minimum & Maximum & Mean & $\begin{array}{c}\text { Standard } \\
\text { deviation }\end{array}$ \\
\hline Return on assets & 0 & 0.734 & 0.075 & 0.053 \\
\hline Stability of the banking relationship & 0 & 1 & 0.839 & 0.265 \\
\hline Ownership concentration & 12 & 100 & 90.224 & 16.175 \\
\hline Company size & 2.867 & 10.519 & 6.999 & 1.258 \\
\hline Age & 2 & 89 & 17.289 & 11.132 \\
\hline Debt & 0.011 & 266.090 & 3.635 & 8.111 \\
\hline
\end{tabular}

\section{Results}

The formulated models (see section 3) were estimated using cross-section data (mean value for the study period 2003-07) and panel data. The greater amount of information available in the panel data increases the efficiency of the estimation, decreases the co-linearity between variables allowing effects that are not detectable in pure section or time studies to be identified and measured.

\subsection{Cross-section Analysis}

Table 4 summarizes the estimation results for model 1 in which we propose to analyze the nonlinear effects of the stability of the banking relationship in operating profitability.

Table 4. Nonlinear effect of stability of the banking relationship on operating profitability: cross-section analysis

\begin{tabular}{lrrr}
\hline \multirow{2}{*}{ Estimation } & \multicolumn{3}{c}{ ROA } \\
\cline { 2 - 4 } & Beta Coeffic. & $\mathrm{t}$ & Sig. \\
\hline Constant & 0.11153 & 17.550 & $* * *$ \\
Stability of Banking Rel. & -0.04128 & -2.560 & $* *$ \\
Stability of Banking Rel. ${ }^{2}$ & 0.03316 & 2.687 & $* * *$ \\
Age & -0.00028 & -3.658 & $* * *$ \\
Company Size & -0.00283 & -4.111 & $* * *$ \\
Debt & -0.00076 & -7.486 & $* * *$ \\
& & & \\
\hline
\end{tabular}

*** Significant at $1 \%$ level; ** Significant at $5 \%$ level; * Significant at $10 \%$ level.

The results show a non-linear effect of the stability of the banking relationship on operating profitability. The stability coefficient of the banking relationship variable is negative $\left(\beta_{1}<0\right)$ and its square is positive $\left(\beta_{2}>0\right)$, which represents a U-shaped quadratic relationship, suggesting that in consolidating new relationships, the difficulties felt by the company to overcome the problems of adverse selection and moral hazard are reflect negatively on profitability. However, insofar as the company solidifies the relationship and banking institutions acquire information, the supervision and monitoring costs decrease, credit constraints lower and the contractual conditions adjusted to business needs, affecting profitability positively.

Quadratic specification proposed has only one inflection point which can be determined by deriving the function with respect to the stability of the banking relationship. Calculating the first derivative and equating to zero, we obtain the value of the variable where the function reaches an extreme. Since the coefficient of the highest degree term is positive (0.03316), the function has a minimum at $\mathrm{C}_{1}=-\left(\beta_{1} / 2 \beta_{2}\right)$, which for the sample under study is 0.622 . The results suggest that the problems of adverse selection and moral hazard lead the bank to require $a$ priori interest rates, higher collateral and more restrictive contractual terms. This problem leads many companies to forego good investment opportunities, conditioning its operating profitability (Parlour and Plantin, 2008, Berndt and Gupa 2009, Degryse et al., 2011). To the extent that the company can establish stable relationships, negotiating flexibility is improved, control exerted by the credit entity is increased, its reputation and confidentiality develops, and can thereby optimize decisions and increase expected returns (Ongena and Smith, 2000, Cánovas and Solano, 2010 
Cánovas and Kant, 2011). The stability of the relationship allows the company to concede "valuable" information essential to making resources available by the credit institution.

As for the effect of the control variables on operating profitability, the results show that they all have a statistically significant effect on the dependent variable. The negative effect of age on operational performance supports the thesis that companies do not have an infinite life expectancy. According to this line of argument, firm age reflects the number of years that it can expect to produce results: the greater the age, the fewer the number of years it will have to generate results (Reis and Augusto, 2013). Still in line with Sharmaa et al. (2007), the negative effect of age on operational performance provides empirical support to the thesis which argues that as the property is increasingly shared, conflicts may emerge if the interests are not aligned. In addition, the line Fok et al. (2004) suggest based on the life cycle of the company, as the company matures, investment opportunities are more limited, its assets and equity increase, resulting in decreased efficiency in their use.

In terms of the role played by company size on operating profitability, this proves to be significant with a negative impact. This result provides support for the argument that in small businesses in general and micro-enterprises in particular, the same person, or a limited number of people (family), simultaneously performs the role of owner and manager, and the line between personal and company assets very tenuous. This circumstance leads them to be more cautious in considering their operational and strategic decisions, being geared towards maximizing value and minimizing operational and financial risk as Riahi-Belkaoui (1998) also concludes.

Regarding the negative impact of debt level on operating profitability, the results suggest that the credit institution's difficulty in controlling the behaviour of the firm (moral hazard) imposes higher interest rates and collateral and more restrictive contractual terms, causing companies to forego good investment opportunities in many situations conditioning performance (Degryse et al., 2011).

Estimation results of the relationship between ownership concentration and operating profitability (Model 2) are summarized in Table 5 .

Table 5. Nonlinear effect of ownership concentration on operating profitability: cross-section analysis

\begin{tabular}{|c|c|c|c|}
\hline \multirow[b]{2}{*}{ Estimation } & \multicolumn{3}{|c|}{ ROA } \\
\hline & Beta Coeffic. & $\mathrm{t}$ & Sig. \\
\hline Constant & 0.12073 & 10.260 & $* * *$ \\
\hline Stability of Banking Rel. & -0.00061 & -2.053 & ** \\
\hline Stability of Banking Rel. ${ }^{2}$ & $4.5815 \mathrm{e}^{-6}$ & 2.167 & $* *$ \\
\hline Age & -0.00027 & -3.513 & $* * *$ \\
\hline Company Size & -0.00314 & -4.626 & $* * *$ \\
\hline Debt & -0.00076 & -7.495 & $* * *$ \\
\hline
\end{tabular}

*** Significant at $1 \%$ level; ** Significant at $5 \%$ level; * Significant at $10 \%$ level.

In line with what has been postulated, the results also show a non-linear effect of concentration on operating profitability, expressed at the significance level of the regression coefficients. Particularly, the coefficient of the ownership concentration variable is negative $\left(\beta_{1}<0\right)$ and its square positive $\left(\beta_{2}>0\right)$. Since the coefficient of the highest degree term is positive, we have a $\mathrm{U}$-shaped quadratic relationship with a minimum at $\mathrm{C}_{1}=-\left(\beta_{1} / 2 \beta_{2}\right)$, which is $66,57 \%$ for the sample under study. As the $\beta_{2}$ coefficient is a very low value, it is sign that the parabola has a very open U shape. The results are consistent with the findings by Hu and Izumida (2008) in a study conducted in Japan on small family businesses. Nevertheless, they are contrary to the findings by Miguel et al. (2004) who identified an inverted U-shaped relationship in a study of listed Spanish companies. In turn, Arosa et al. (2010) and Westhead and Howorth (2006), did not identify any statistically significant relationship.

The quadratic U-shaped relationship indicates that for low levels of control rights the expropriation hypothesis prevails and at higher levels of ownership concentration, the supervision hypothesis. The inverse relationship demonstrated by our results between ownership concentration and operating profitability for low concentration levels, suggests that two potential effects prevail. On the one hand, there is an incentive for the owner to take actions that increase personal utility, reducing corporate performance - as Anderson and Reeb (2003) also conclude - and less efficient investment 
decisions may be associated with these actions (Cronqvist and Nilsson , 2003). On the other hand, in line with Gomez-Mejia et al. (2001), the findings suggest that as ownership concentration increases there is a greater influence of control on the manager, which may lead to greater entrenchment. The inversion of concavity in the quadratic relationship, relative to what is obtained by other studies focusing on large companies (e.g., Holderness, 2003, Miguel et al., 2004) is related to the fact that the latter have an external control system, professional management and a more dispersed ownership, where the equity holders buy and sell stocks in high liquidity markets. In listed companies, ownership loses its relevance as the supervisory mechanism, as this is ensured by external forces (e.g. the market, laws/regulations). In contrast, in small businesses, internal control systems, a more highly concentrated ownership predominate, and control by securities markets is not felt. The ownership structure of these companies plays an important role in disciplining managers and significantly determines profitability for lack of effective external control mechanisms.

The impact of the control variables on profitability does not change when compared with results obtained when estimating model 1 (see Table 4).

\subsection{Estimation with Panel Data}

In the previous subsection, the models were estimated with cross-section data (mean values (2003-07). In this section, we expand the field of analysis and estimate models with panel data (2003-07), in order to capture the distinctive characteristics of individuals which may not be constant over time (heterogeneity) and reduce bias in the estimated parameters.

The following generic specification was considered for a model of panel data referring to section unit $i$ at time $t$

$$
Y_{i t}=\beta_{0 i t}+\sum_{i=1}^{k} \beta_{k i t} X_{i t}+\varepsilon_{i t} \quad \mathrm{i}=1, \ldots \mathrm{N} \quad \mathrm{t}=1, \ldots \mathrm{T}
$$

Where :

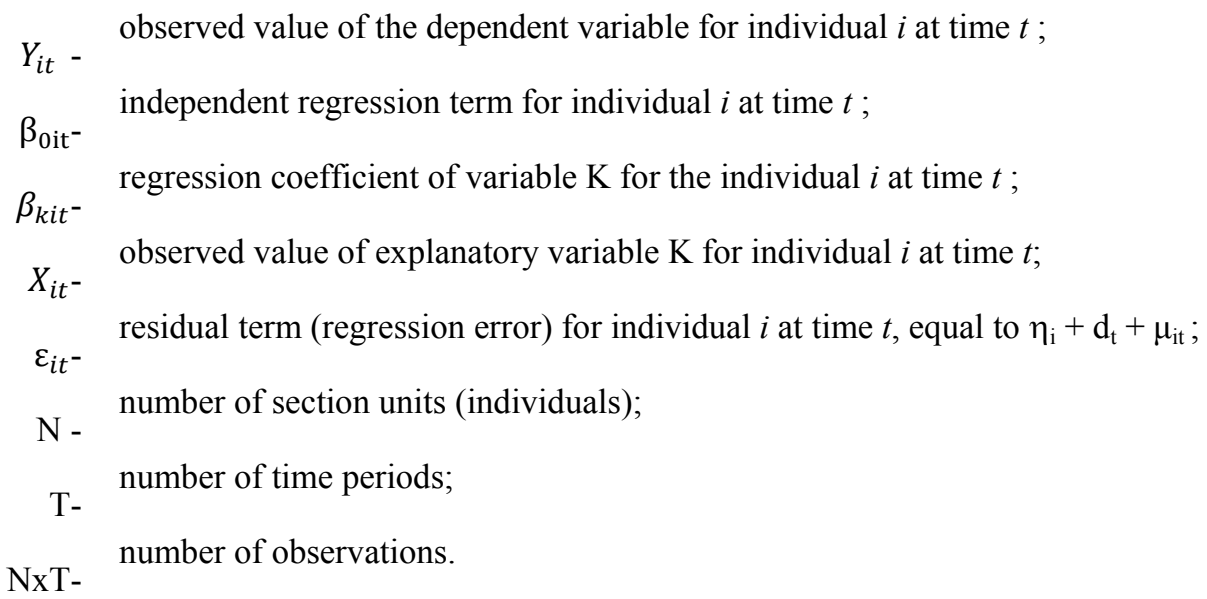

In the considered model the error term, $\varepsilon_{i t}$, is divided into three distinct components: the individual effect, $\eta_{\mathrm{i}}$; the time effect, $d_{t}$ and random perturbation, $\mu_{\mathrm{it}}$. The term $\varepsilon_{i t}$ captures all unobserved factors, constant in time, conditioning $Y_{i t}$. The fact of $\eta_{i}$ does not have index $t$ results from the fact that it does not change over time. Generically, it is referred to as an unobserved effect, or a fixed effect. The term $d_{t}$ is a dummy variable that does not change with individuals $i$, which is why it is omitted. The term $\mu_{\mathrm{it}}$ is designated idiosyncratic error or error due to temporal variation, because it represents unobserved factors which change over time and condition $Y_{i t}$.

Decomposition of the error term allows the panel data methodology to consider the unobserved effect, $\eta_{i}$, is correlated with the explanatory variables. Since $\eta_{\mathrm{i}}$ is constant over time, data over two consecutive periods can be distinguished, yielding the new equation, called the first differences equation, where $\eta_{i}$ does not appear (it was eliminated by differentiation). Thus, the Generalized Method of Moments (GMM) is used in estimating our models allowing endogeneity problems to be controlled using instruments.

Adopting this methodology in estimating the model leads to changing how the stability of the banking relationship is evaluated. It will be measured by the ratio between ordinary banks during two consecutive years and the number of banks the company establishes relationships with in the same period.

GMM estimators with panel data were used to estimate the models using xtabond 2 developed by Roodman (2006). To eliminate the individual effects, the models were estimated after considering the first differences for the variables. 
The Arellano and Bond (1991) statistic shows that there is no autocorrelation in the error term (significance of 0.294 and 0.311 for model 1 and 2, respectively) and the J test proposed by Hansen (1999) due to the quality of the instruments: is a restriction test of over identification, asymptotically distributed as $\chi^{2}$ under the null hypothesis of no correlation between the instruments and the error term (significance of 0.667 and 0.171 for model 1 and 2 , respectively).

The estimation results for models 1 and 2 are summarized in Table 6 and 7 respectively, with all significant coefficients of the independent variables. Regarding the results of the model 1 estimation, the coefficient of relative stability remains negative $\left(\beta_{1}<0\right)$ and its square positive $\left(\beta_{2}>0\right)$, validating the quadratic relationship identified in the cross-section estimation. As for the control variables, only the effect of company size on profitability changes, becoming positive. This result is consistent with Damanpour (2010), who documents that size in boosting innovation in the medium and long term, it leverages the company's performance.

Table 6. Nonlinear effect of stability of the banking relationship on operating profitability: panel data analysis

\begin{tabular}{lrrr}
\hline \multirow{2}{*}{ Estimation } & \multicolumn{3}{c}{ ROA } \\
\cline { 2 - 4 } & Beta Coeffic. & $\mathrm{t}$ & Sig. \\
\hline Constant & 0.3086122 & 7.00 & $* * *$ \\
Stability of Banking Rel. & -0.1432666 & -2.58 & $* *$ \\
Stability of Banking Rel. ${ }^{2}$ & 0.0919268 & 2.34 & $* *$ \\
Age & -0.0059876 & -5.42 & $* * *$ \\
Company Size & 0.0192677 & 3.56 & $* * *$ \\
Debt & -0.0710583 & -5.09 & $* * *$ \\
$D_{(t-3)}$ & 0.0598587 & 3.51 & $* * *$ \\
$D_{(t-2)}$ & 0.0122277 & 4.01 & $* * *$ \\
$D_{(t-1)}$ & 0.0205728 & 2.38 & $* *$ \\
$D_{(t)}$ & & & \\
\hline AR(2) & -1.05 & & 0.294 \\
Hansen & 1.57 & & 0.667 \\
\hline
\end{tabular}

*** Significant at $1 \%$ level; ** Significant at $5 \%$ level; * Significant at $10 \%$ level.

As for model 2, the analysis of the results in Table 7 upholds the previous argument.

Table 7. Nonlinear effect of ownership concentration on operating profitability: panel data analysis

\begin{tabular}{lrrr}
\hline \multirow{2}{*}{ Estimation } & \multicolumn{3}{c}{ ROA } \\
\cline { 2 - 4 } & Beta Coeffic. & $\mathrm{t}$ & \multicolumn{1}{c}{ Sig. } \\
\hline Constant & 0.1865961 & 5.01 & $* * *$ \\
Stability of Banking Rel. & -0.0013214 & -2.42 & $* *$ \\
Stability of Banking Rel. ${ }^{2}$ & 0.0000174 & 3.66 & $* * *$ \\
Age $_{\text {Company Size }}$ & -0.0049574 & -5.35 & $* * *$ \\
Debt & 0.0169272 & 3.31 & $* * *$ \\
$D_{(t-3)}$ & -0.0575299 & -4.93 & $* * *$ \\
$D_{(t-2)}$ & 0.0479081 & 2.95 & $* * *$ \\
$D_{(t-1)}$ & 0.0134468 & 3.93 & $* * *$ \\
$D_{(t)}$ & 0.0271212 & 3.14 & $* * *$ \\
AR(2) $_{\text {Hansen }}$ & & & \\
\hline
\end{tabular}

*** Significant at $1 \%$ level; ** Significant at $5 \%$ level; * Significant at $10 \%$ level. 


\section{Conclusion}

In this study, using a sample of 4163 SMEs, cross-section and panel data, additional empirical evidence is provided for the effect of the stability of the banking relationship and ownership concentration on operational performance. This issue is of particular importance for companies as individual entities at the level of aggregate economic activity, financial stability and even at the level of the financial system architecture. In addition, our empirical analysis focuses on the Portuguese SMEs, an economy where these companies represent over $99.5 \%$ of business units and where the banking system plays a central role in financing these businesses units.

A non-linear relationship supported by our results between the stability of the banking relationship and operational performance suggests a U-shaped quadratic relationship between the two variables. This result clearly indicates that in consolidating new relationships, SMEs are confronted with great difficulties in overcoming problems that result from the information asymmetries they are exposed to. This situation leads banks to require $a$ priori interest rates and higher collateral and impose more restrictive terms in credit agreements. As a result, many SMEs find themselves obliged to forego value creating investment opportunities or to be subject to interest rates and restrictive terms to obtain credit they would avoid in other situations, which is duly reflected in operational performance. However, to the extent that SMEs can solidify the banking relationship and credit institutions acquire information and decrease supervision and control costs, improve their bargaining power, develop their reputation and confidentiality, they face lower credit constraints and contractual conditions tend to adapt to their funding needs with corresponding reflections on performance.

When analyzing the effect of ownership concentration on performance, the U-shaped quadratic relationship means that for low levels of control rights expropriation hypothesis prevails and for higher levels the supervision hypothesis. The negative effect of ownership concentration in operating profitability for low concentration levels, suggests that two potential effects prevail: $i$ ) the owner's incentive to take actions that increase personal utility at the expense of maximizing company value and ii) as ownership concentration increases, a controlling influence on managers is found, which can lead to greater entrenchment. These results were shown to be robust when considering cross-section and panel data.

This study takes the "state of the art" a step forward in that it reveals that: $i$ ) the problems of adverse selection and moral hazard originated by information asymmetry constitute an obstacle for the company to establish stable relationships; however, insofar as the relationship solidifies, bargaining power and funding conditions improve, there are positive impacts on expected earnings, ii) it was also possible to validate that the relationship of ownership concentration with profitability depends on the prevalence of two effects: the expropriation effect (for low concentration levels) and the supervision effect (for higher levels).

\section{References}

Agrawal, A., \& Mandelker, N. (1990). Large shareholders and the monitiring of management: the case of antitakover charter amendments. Journal of Finance and Quantitativa Analysis, 25(2), 143-161. http://dx.doi.org/10.2307/2330821

Almeida, H., \& Campello, M. (2007). Financial constraints, asset tangibility, and corporate investment. Review of Financial Studies, 20(5), 1429-1460. http://dx.doi.org/10.1093/rfs/hhm019

Anderson, C., \& Reeb, M. (2003). Founding-family ownership and firm performance: Evidence from the S\&P 500. The Journal of Finnace, 58(3), 1301-1327. http://dx.doi.org/10.1111/1540-6261.00567

Andres, C. (2008). Large shareholders and firm performance. An empirical examination of founding-family ownership. Journal of Corporate Finance, 14(4), 431-445. http://dx.doi.org/10.1016/j.jcorpfin.2008.05.003

Aras, G., Aybars, A., \& Kutlu, O. (2010). Managing corporate performance: Investigating the relationship between corporate social responsibility and financial performance in emerging markets. International Journal of Productivity and Performance Management, 59(3), 229-254. http://dx.doi.org/10.1108/17410401011023573

Arellano, M., \& Bond, S. (1991). Some tests of specification for panel data: Monte Carlo evidence and an application to employment equations. Review of Economic Studies, 58(2), 277-297. http://dx.doi.org/10.2307/2297968

Arosa, B., Iturralde, T., \& Maseda, A. (2010). Ownership structure and firm performance in non-listed firms: Evidence from Spain. Journal of Family Business Strategy, 1(2), 88-96. http://dx.doi.org/10.1016/j.jfbs.2010.03.001

Augusto, M.G., Lisboa, J.V., \& Brandão, E.F. (2011). Dividend policy and capital structure: An empirical application in the Portuguese corporate context. International Journal of Decision Sciences, Risk and Management, 3(1\&2), $2-31$. 
Beck, T., Demirgüç-Kunt, A., \& Maksimovic, V. (2005). Financial and legal constraints to firm growth: Does firm size matter. The Journal of Finance, 60(1), 137-177.

Beck, T., Demirgüç-Kunt, A., Laeven, L., \& Maksimovic, V. (2006). The determinants of financing obstacles. Journal of International Money and Finance, 25(6), 932-935. http://dx.doi.org/10.1016/j.jimonfin.2006.07.005

Behr, P., Norden, L., \& Noth, F. (2013). Financial constraints of private firms and bank behavior. Journal of Banking \& Finance, 37(9), 3472-3485. http://dx.doi.org/10.1016/j.jbankfin.2013.05.018

Bennedsen, M., Nielsen, K., Perez-Gonzalez, F., \& Wolfenzon, D. (2007). Inside the family firm: The role of families in succession decisions and performance. The Quarterly Journal of Economics, 122(2), 647-691.

Berger, A., \& Udell, F. (1995). Relationship lending and lines of credit in small firm finance. Journal of Business, 68(3), 351-381. http://dx.doi.org/10.1086/296668

Berndt, A., \& Gupa, A. (2009). Moral hazard and adverse selection in the originate-to-distribute model of bank credit. Journal of Monetary Economics, 56(5), 725-743. http://dx.doi.org/10.1016/j.jmoneco.2009.04.002

Bhagat, S., \& Bolton, B. (2008). Corporate governance and firm performance. Journal of Corporate Governance, 14(3), 257-273. http://dx.doi.org/10.1016/j.jcorpfin.2008.03.006

Bharath, S., Dahiya, S., Saunders, A., \& Srinivasan, A. (2011). Lending relationship and loan contract terms. Review of Financial Studies, 24(4), 1141-1203. http://dx.doi.org/10.1093/rfs/hhp064

Bhattacharya U., \& Ravikumar B. (2001). Capital markets and the evolution of family business. Journal of Business, 74(2), 187-220. http://dx.doi.org/10.1086/209670

Bolbol, A., Fatheldin, A., \& Omran, M. (2004). Ownership Structure, Firm Performance, and Corporate Governance: Evidence from Selected Arab Countries. Working Paper Abu Dhabi, Arab Monetary Fund.

Bonfim, D, Dai, Q., \& Franco, F. (2010). Relações bancárias e custos de financiamento. Relatório de estabilidade financeira, Banco de Portugal, 163-180.

Boot, A. (2000). Relationship banking: What do we know?. Journal of Financial Intermediation, 9(1), 7-25.

Boot, A., Greembaum, S., \& Thakor, A. (1993). Reputation and discretion in financial contracting. American Economic Review, 83(5), 1165-1183.

Bruton, D., Filatotchev, I., Chahine, S., \& Wright, M. (2010). Governance, ownership structure, and performance of IPO firms: the impact of different types of private equity investors and institutional environments. Strategic Management Journal, 31(5), 491-509.

Byun, H., Hwang, L., \& Lee, W. (2011). How does ownership concentration exacerbate information asymmetry among equity investors?. Pacific-Basin Finance Journal, 19(5), 511-534. http://dx.doi.org/10.1016/j.pacfin.2011.06.002

Cánovas, G., \& Kant, J. (2011). SME financing in Europe: Cross-country determinants of bank loan maturity. International Business Journal, 29(5), 489-507.

Cánovas, G., \& Solano, P. (2007). Effect of the number of banking relationship on credit availability: Evidence from panel data of Spain small firm. Small Business Economics, 28(1), 37-53. http://dx.doi.org/10.1007/s11187-005-6704-z

Cánovas, G., \& Solano, P. (2010). Relationship lending and SME financing in the continental European bank-based system. Small Business Economics, 34(4), 465-482. http://dx.doi.org/10.1007/s11187-008-9129-7

Cardone, C., Casasola, M., \& Samartin, M. (2005). Do banking relationships improve credit conditions for Spanish SMEs?. Business Economics Working Paper 05-28

Castelli, A., Dwyer, P., \& Hasan, I. (2012). Bank Relationships and Firms' Financial Performance: The Italian Experience. European Financial Management, 18(1), 28-67.

Chen, S., Ho, W., Lee, C., \& Shrestha, K. (2004). Nonlinear models in corporate finance research: review, critique, and extensions. Review of Quantitative Finance and Accounting, 22(2), 141-169.

Chrisman, J., Chua, H., \& Sharma, P. (2005). Trends and directions in the development of a strategic management theory of the family firm. Entrepreneurship theory and practice, 29(5), 555-576.

Chu, W. (2009). The influence of family ownership on SME performance: evidence from public firms in Taiwan. Small Business Economics, 33(3), 353-373. http://dx.doi.org/10.1007/s11187-009-9178-6 
Chu, W. (2011). Family ownership and firm performance: Influence of family management, family control, and firm size. Asia Pacific Journal of Management, 28(4), 833-851. http://dx.doi.org/10.1007/s10490-009-9180-1

Cronqvist, H., \& Nilsson, M. (2003). Agency cost of controlling minority shareholders. Journal of Financial and Quantitative Analysis, 38(4), 695-719. http://dx.doi.org/10.2307/4126740

Cuervo, A. (2002). Corporate governance mechanisms: a plea for less code of god governance and more market control. Corporate governance: An International Review, 10(2), 84-93.

Dahya J., Dimitrov O., \& McConnell J. (2008). Dominant shareholders, corporate boards and corporate value: A cross-country analysis. Journal of Financial Economics, 87(1), 73-100.

Damanpour, F. (2010). An integration of research findings of effects of firm size and market competition on product and process innovations. British Journal of Management, 21(4), 996-1010.

Dass, N., \& Massa, M. (2011). The impact of strong bank-firm relationship on the borrowing firm. Review of Financial Studies, 24(4), 1204-1260. http://dx.doi.org/10.1093/rfs/hhp074

De Bodt, E., Lobez, F., Statnik, C. (2005). Credit rationing, customer relationship and the number of banks: An empirical analysis. European Financial Management, 11(2), 195-228.

De la Torre, A., Martínez Pería, M., \& Schmukler, L. (2010). Bank involvement with SMEs: beyond relationship lending. Journal of Banking \& Finance, 34(9), 2280-2293. http://dx.doi.org/10.1016/j.jbankfin.2010.02.014

DeAngelo, H, DeAngelo, L., \& Wruck, K. (2002). Asset liquidity, debt covenants, and managerial discretion in financial distress: the collapse of L.A. Gear. Journal of Finance Economics, 64(1), 3-34.

Degryse, H., \& Ongena, S. (2001). Bank relationships and firm profitability. Financial Management, 30(1), 9-34.

Degryse, H., \& Van Cayseele P. (2000). Relationship Lending Within a Bank-Based System: Evidence from European Small Business Data. Journal of Financial Intermediation, 9(1), 90-109. http://dx.doi.org/10.1006/jfin.1999.0278

Degryse, H., Masschelein, N., \& Mitchell, J. (2011). Staying, dropping, or switching: the impacts of bank mergers on small firms. Review of Financial Studies, 24(4), 1102-1140. http://dx.doi.org/10.1093/rfs/hhp126

Demsetz, H., \& Lehn, K. (1985). The structure of corporate ownership: causes and consequences. Journal of Political Economics, 93(6), 1155-1177. http://dx.doi.org/10.1086/261354

Dennis, S., Nandy, D., \& Sharpe, I. (2000). The determinants of contract terms in bank revolving credit agreements. Journal of Financial and Quantitative Analysis, 35(1), 87-110. http://dx.doi.org/10.2307/2676240

Detragiache, E., Garella, P., \& Guiso, L. (2000). Multiple versus single banking relationships: Theory and evidence. The Journal of Finance, 55(3), 1133-1161. http://dx.doi.org/10.1111/0022-1082.00243

Diamond, D. (1984). Financial intermediation and delegated monitoring. Review of Economic Studies, 51(3), $393-414$.

Ding, H., Cai, J., \& Niu, Y. (2012). Correlations between Executive Pay, Equity Incentive and Corporate Performance: Empirical Analysis Based on Panel Data of China's Listed Companies. International Journal of Financial Research, 3(3), 24-31.

Eddleston, K., Kellermanns, F., \& Sarathy, R. (2008). Resource configuration in family firms: Linking resources, strategic planning and technological opportunities to performance. Journal of Management Studies, 45(1), 26-50.

Ehikioya, B. (2009). Corporate governance structure and firm performance in developing economies: evidence from Nigeria. Corporate Governance, 9(3), 231-243. http://dx.doi.org/10.1108/14720700910964307

Elsas, R. (2005). Empirical determinants of relationship lending. Journal of Financial Intermediation, 14(1), 32-57.

Emma G., \& Juan B., (2011). Firm value and ownership structure in the Spanish capital market. Corporate Governance, 11(1), 41-53. http://dx.doi.org/10.1108/14720701111108835

Farinha, L., \& Santos, J. (2002). Switching from single to multiple bank lending relationships: Determinants and implications. Journal of Financial Intermediation, 11(2), 124-151. http://dx.doi.org/10.1006/jfin.2001.0328

Fazzari, S., Hubbard, G., \& Peterson, B. (1988). Financing Constraints and Corporate Investment. Brooking Papers on Economic, 141-206. http://dx.doi.org/10.2307/2534426

Fok, C., Chang, \& Y., Lee, T. (2004). Bank relationships and their effects on firm performance around the Asian financial crisis: Evidence from Taiwan. Financial Management, 33(2), 89-112. 
Gadhoum Y., Lang L., \& Young L. (2005). Who controls US?. European Financial Management, 11(3), 339-363.

Gedajlovic, E., \& Shapiro, D. (1998). Management and ownership effects: evidence from five countries. Strategic Management Journal, 19(6), 533-553. http://dx.doi.org/10.1002/(SICI)1097-0266(199806)19:6<533::AID-SMJ957>3.0.CO;2-\#

Goergen, M., \& Renneboog, L. (2008). Contractual corporate governance. Journal of Corporate Finance, 14(3), 166-182. http://dx.doi.org/10.1016/j.jcorpfin.2008.04.003

Gomez-Mejia, L., Nunez-Nickel, M., \& Gutierrez, I. (2001). The role of family ties in agency contracts. The Academy of Management Journal, 44(1), 81-95. http://dx.doi.org/10.2307/3069338

Gorton, G., \& Schmid, A. (2000). Universal Banking and the Performance of German Firms. Journal of Financial Economics, 58(1-2), 29-80. http://dx.doi.org/10.1016/S0304-405X(00)00066-0

Greenaway, D., Guariglia, A., \& Yu, Z. (2012, June). The more the better? Foreign ownership and corporate performance in China. The European Journal of Finance, 1-22.

Griner. (2011). Corporate Performance, Stock Option Compensation, and Measurement Error in CEO Pay. Journal Of Applied Business Research, 12(1), 1-11.

Grossman, S., \& Hart, O. (1986). The Costs and Benefits of Ownership: A Theory of Vertical and Lateral Integrat. Journal of Political Economy, 94(4), 691-719. http://dx.doi.org/10.1086/261404

Hadlock, C., \& Pierce, J. (2010). New evidence on measuring financial constraints: Moving beyond the KZ index. Review of Financial Studies, 23(5), 1909-1940. http://dx.doi.org/10.1093/rfs/hhq009

Hamadi, M. (2010). Ownership concentration, family control and performance of firms. European Management Review, 7(2), 116-131. http://dx.doi.org/10.1057/emr.2010.9

Hansen, B. (1999). Testing for linearity. Journal of Economic Surveys, 13(5), 551-576.

Harford, J., Mansi, S., \& Maxwell, W. (2008). Corporate governance and firm cash holding in the US. Journal of Financial Economics, 87(3), 535-555. http://dx.doi.org/10.1016/j.jfineco.2007.04.002

Harhoff, D., \& Körting, T. (1998). Lending relationships in Germany - Empirical evidence from survey data. Journal of Banking \& Finance, 22(10), 1317-1353. http://dx.doi.org/10.1016/S0378-4266(98)00061-2

Hill, C., \& Snell, S. (1988). External control, corporate strategy, and firm performance in research-intensive industries. Strategic Management Journal, 9(6), 577-590. http://dx.doi.org/10.1002/smj.4250090605

Holderness, C. (2003). A Survey of Blockholders and Corporate Control. Economic Policy Review, 9(1), 51-64.

Hu, Y., \& Izumida, S. (2008). Ownership Concentration and Corporate Performance: A Causal Analysis with Japanese Panel Data. Corporate Governance - An International Review, 16(4), 342-358.

IAPMEI. (2008). Sobre as PME em Portugal. Direção de Planeamento e Estudos.

Ivashina, V. (2009). Asymmetric information effects on loan spreads. Journal of Financial Economics, 92(2), 300-319. http://dx.doi.org/10.1016/j.jfineco.2008.06.003

Jensen, C., \& Meckling, H. (1976). Theory of the firm: managerial behaviour, agency cost and ownership structure. Journal of Financal Economic, 3(4), 305-360. http://dx.doi.org/10.1016/0304-405X(76)90026-X

Joh, S. (2003). Corporate Governance and Firm Profitability: Evidence from Korea before the Economic Crisis. Journal of Financial Economics, 68(2), 287-322. http://dx.doi.org/10.1016/S0304-405X(03)00068-0

Kaplan, N., \& Minton, B. (1994). Appointments of Outsiders to Japanese Boards: Determinants and Implications for Managers. Journal of Financial Economics, 36(2), 225-258. http://dx.doi.org/10.1016/0304-405X(94)90025-6

Kaplan, S., \& Zingales, L. (1997). Do investment-cash flow sensitivities provide useful measure of financing constraints. Quarterly Journal of Economics, 112(1), 169-215. http://dx.doi.org/10.1162/003355397555163

Komnenic, B., \& Pokrajcic, D. (2012). Intellectual capital and corporate performance of MNCs in Serbia. Journal of Intellectual Capital, 13(1), 106-119. http://dx.doi.org/10.1108/14691931211196231

Kurt H., Abeyratna G., \& Martin H. (2010). State-dominant and non-state-dominant ownership concentration and firm performance: Evidence from China. International Journal of Managerial Finance, 6(4), 264-289.

La Porta, R., López, S., Shleifer, A., \& Vishny, R. (1998). Law and Finance. Journal of Political Economy, 106(6), 1113-1155. http://dx.doi.org/10.1086/250042 
La Porta, R., López, S., Shleifer, A., \& Vishny, R. (1999). The quality of government. Journal of Law, Economics and Organization, 15(1), 222-279. http://dx.doi.org/10.1093/jleo/15.1.222

Langlais, E. (1999). Les effets d'antisélection lorsque le principal et les agents ont des croyances différents - une illustration dans le cas di marché du crédit. Revue D'Economie Politique, 109(4), 513-533.

Larmou, S., \& Vafeas, N. (2010). The relation between board size and firm performance in firms with a history of poor operational performance. Journal of Management \& Governance, 14(1), 61-85.

Leech, D., \& Leahy, J. (1991). Ownership structure, control type classifications and the performance of large British companies. Economic Journal, 101(409), 1418-1437. http://dx.doi.org/10.2307/2234893

Lehmann, E., \& Weigand, J. (2000). Does de governed corpotation perform better? Governance structures and corporate performance in Germany. European Finance Review, 4(2), 157-195.

Leland, H. (1998). Agency Costs, Risk Management, and Capital Structure. The Journal of Finance, 53(4), 1213-1243.

Leland, H., \& Toft, B. (1996). Optimal Capital Structure, Endogenous Bankruptcy, and the Term Structure of Credit Spreads. The Journal of Finance, 51(3), 987-1019. http://dx.doi.org/10.1111/j.1540-6261.1996.tb02714.x

Ma, S., Naughton, T., \& Tian, G. (2010). Ownership and ownership concentration: witch is important in determining the performance of China's listed firms?. Accounting \& Finance, 59(4), 871-897.

Margaritis, D., \& Psillaki, M. (2010). Capital structure, equity ownership and firm performance. Journal of Banking \& Finance, 34(3), 621-632. http://dx.doi.org/10.1016/j.jbankfin.2009.08.023

Masulis, R, Wang, C., \& Xie, F. (2012). Globalizing the boardroom - The effects of foreign directors on corporate governance and firm performance. Journal of Accounting and Economics, 53(3), 527-554.

Maury B. (2006). Family ownership and firm performance: Empirical evidence from Western European corporations. Journal of Corporate Finance, 12(2), 321-341. http://dx.doi.org/10.1016/j.jcorpfin.2005.02.002

Miguel, A., Pindado, J., \& Torre, L. (2004). Ownership structure and firm value: new evidence from the Spanish corporate governance system. Strategic Management Journal, 25(12), 1199-1207.

Minguez-Vera, A., \& Martin-Uego, J. (2007). Does Ownership Structure Affect Value? Evidence from the Spanish Capital Market. International Review of Financial Analysis, 16(1), 81-98.

Mudambi, R., \& Nicosia, C. (1998). Ownership struture and firm performance: evidence from U.K. financial services industry. Applied Financial Economics, 8(2), 175-180. http://dx.doi.org/10.1080/096031098333159

Myers, S., \& Majluf, N. (1984). Corporate financing and investment decisions when firms have information that investors do not have. Journal of Financial Economics, 13(2), 187-221.

Ongena, S., \& Smith, C. (2000). What determines the number of bank relationships? Cross-country evidence. Journal of Financial Intermediation, 9(1), 26-56. http://dx.doi.org/10.1006/jfin.1999.0273

Park, C. (2000). Monitoring and Structure of Debt Contracts. The Journal of Finance, 55(5), 2157-2195.

Parlour, C., \& Plantin, G. (2008). Loan Sales and Relationship Banking. The Journal of Finance, 63(3), 1291-1314.

Petersen, M., \& Rajan, R. (1994). The benefits of lending relationship: Evidence from small business data. The Journal of Finance, 49(1), 3-37. http://dx.doi.org/10.1111/j.1540-6261.1994.tb04418.x

Psillaki, M. (1995). Rationnement du crédit et PME: une tentative de mise en relation. Revue International PME, 8(3-4), 67-90.

Puri, M., \& Rocholl, J. (2008). On the importance of retail banking relationships. Journal of Financial Economics, 89(2), 253-267. http://dx.doi.org/10.1016/j.jfineco.2007.07.005

Rajan, G. (1992). Insiders and outsiders: the choice between informed and arm's length debt. The Journal of Finance, 48(4), 1367-1400. http://dx.doi.org/10.1111/j.1540-6261.1992.tb04662.x

Ramakrishnam, R., \& Thakor, A. (1984). Information reliability and theory of financial intermediation. Review of Economic Studies, 52(3), 415-432. http://dx.doi.org/10.2307/2297431

Reis, P., \& Augusto, M. (2013). Business mortality table: The average of life expectancy as a fundamental instrument in calculation of the terminal or continuing value in enterprise valuation. Atas da $3^{\text {rd }}$ International Network of Business and Management Journals (INBAM), 17-19 de junho, Universidade Técnica de Lisboa, Lisboa, Portugal (22 p.) 
Riahi-Belkaoui, A. (1998). The effects of the degree of internationalization on firm performance. International Business Review, 7(3), 315-321. http://dx.doi.org/10.1016/S0969-5931(98)00013-4

Roodman, D. (2006). How to do Xtabond2: An Introduction to Difference and System GMM in Stata. Center for Global Development Working Paper No. 103.

Sakai, K., Uesugi, I., \& Watanabe, T. (2010). Firm age and the evolution of borrowing costs: Evidence from Japanese small firms. Journal of Banking \& Finance, 34(8), 1970-1981. http://dx.doi.org/10.1016/j.jbankfin.2010.01.001

Schenone, C. (2010). Lending relationship and information rents: Do bank exploit their information advantage. Review of Finance Studies, 23(3), 1149-1199. http://dx.doi.org/10.1093/rfs/hhp080

Sharmaa, P., Hoyb, F., Astrachanc, J., \& Koiranen, M. (2007). The practice-driven evolution of family business educacion. Journal of Business Research, 60(10), 1012-1021. http://dx.doi.org/10.1016/j.jbusres.2006.12.010

Sharpe, S. (1990). Asymmetric information, bank lending and implicit contracts: a stylized model of customer relationship. The Journal of Finance, 45(4), 1069-1087.

Shimizu, K. (2012). Bankruptcies of small firms and lending relationship. Journal of Banking \& Finance, 36(2), 857-870. http://dx.doi.org/10.1016/j.jbankfin.2011.09.016

Shleifer, A., \& Vishny, R. (1986). Large shareholders and corporate control. Journal of Political Economy, 94(3), 458-461. http://dx.doi.org/10.1086/261385

Shleifer, A., \& Vishny, R. (1997). A survey of corporate governance. The Journal of Finance, 52(2), 737-783.

Stiglitz, J., \& Weiss, A. (1981). Credit Rationing in Markets with imperfect information. The American Economic Review, 71(3), 393-410.

Thomsen, S. (2005). Conflicts of Interest or Aligned Incentives? Block-holder Ownership, Dividends and Firm Value in the US and the EU. Working European Business Organization Law Review, 6, 201-225.

Torre, A., Pería, M., \& Schmukler, S. (2010). Bank involvement with SMEs: Beyond relationship lending. Journal of Finance \& Banking, 34(9), 2280-2293. http://dx.doi.org/10.1016/j.jbankfin.2010.02.014

Tsionas, M., Merikas, A., \& Merika, A., (2012). Concentrated ownership and corporate performance revisited: The case of shipping. Transportation Research Part, 48(4), 843-852. http://dx.doi.org/10.1016/j.tre.2012.01.004

Udel, G. (2008). What's in a relationship? The case of commercial lending. Business Horizons, 51(2), 93-103.

Valverde, S., Fernandez, F., \& Udell, G. (2009). Bank Market Power and SME Financing Constraints. Review of Finance, 13(2), 309-340. http://dx.doi.org/10.1093/rof/rfp003

Vigneron, G. (2001). Bank-agent mergers: Never a no-brainer. National Underwriter / Property \& Casualty Risk \& Benefits Management, 105(42), 11.

Villalonga B., \& Amit R. (2006). How do family ownership, control and management affect firm value?. Journal of Financial Economics, 80(2), 385-418. http://dx.doi.org/10.1016/j.jfineco.2004.12.005

Wang, Z., \& Sarkis, J. (2013). Investigating the relationship of sustainable supply chain management with corporate financial performance. International Journal of Productivity and Performance Management, 62(8), 871-888.

Westhead, P., \& Howorth, C. (2006). Ownership and Management Issues Associated With Family Firm Performance and Company Objectives. Family Business Review, 19(4), 301-316. http://dx.doi.org/10.1111/j.1741-6248.2006.00077.x

Whited, T., \& Wu, G. (2006). Financial constraints risk. Review of Financial Studies, 19(2), 531-559. http://dx.doi.org/10.1093/rfs/hhj012

Woodcock, R. (2012). The Effects of Corporate Governance on Company Performance: Evidence from Sri Lankan Financial Services Industry. American Journal of Business and Finance, 2(1), 7-14.

\section{Note}

Note 1. This law defines micro, small and medium businesses. The category of micro, small and medium enterprises (SMEs) is made up of enterprises which employ fewer than 250 people and whose annual turnover does not exceed 50 million euros or whose annual balance sheet total does not exceed 43 million euros. A small business is defined as an enterprise which employs fewer than 50 people and whose annual turnover or annual balance sheet total does not exceed 10 million euros. A micro enterprise is defined as employing fewer than 10 people and whose annual turnover does not exceed 2 million euros. 